\title{
ROTIFERS OF SPRING POOLS IN THE COASTAL MARSHLAND OF ALBUFERA OF VALENCIA NATURAL PARK
}

\author{
M. R.Miracle', M. T. Alfonso', E. Vicente' \& W. Koste'2 \\ 'Departament de Ecologia. Facultat de Biologia. Universitat de Valbncia. 46100 Burjassot (València). Spain \\ ${ }^{2}$ Ludwig-Brill Strasse 5, Quakenbriick. D-4570 Germany.
}

Keywords: rotifers, coastal Mediterranean spring-pools, Dicraizophoridae and Notommatidae new records, Euchlanis dapidula, Asplanchnopus multiceps, Lecane pideis.

Palabras clave: rotiferos, surgencias costeras Mediterráneas, nuevas citas de Dicranophoridae y Notaminidae, Euchlanis dapidula, Asplanchnopus multiceps, Lecane pideis.

\begin{abstract}
The marsh land of the Albufera Natural Park has been subject to intense human impact and most of its area has been devoted to rice fields. However, there is a series of spring pools, i.e. small shallow pools fed by subterranean waters, which are thought to be refuge areas of species which have disappeared from the other more contaminated aquatic habitats. The Rotifer fauna of four of these spring pools was studied from quantitative and net plankton samples, as well as live samples from the littoral zone, to identify bdelloids and other difficult groups. A total of 107 species were identified, some of them quite rare, e.g. Asplanchnopus multiceps, Euchlanis dapidula, Lecane pideis, Erignata saggitoides, Dicranophorus hercules and Paradicranophorushudsoni. Rotifer species diversity of littoral samples was found to be very high, with values of Shannon-Wiener index over 4 bits ind '.
\end{abstract}

\section{INTRODUCTION}

Most coastal wetlands are now heavily polluted, but the richness of species in these environments is still obvious. The Albufera National Park is one of the few areas left from a rosary of wetlands which conformed the Western Mediterranean coast. Interesting species from the biogeographical point of view are found in these wetlands due to their long existence, although subject to great changes in shape and location. In the Valencia region, endemics with Eastern Europe and North African affinities are found, e.g. the ciprinodontid fish Valencia hispanica, the gasteropod Melaizopsis dufouri tricarinata, or the decapod Dugastela valentina (MARGALEF, 1983).

The aquatic ecosystems of the Albufera Natural Park have been exposed to intense human impact (VICENTE \& MIRACLE 1992). Nevertheless there is a large number of spring pools, named locally "ullals" ("ull" means eye in catalan language), which are small and shallow pools fed by water sources, which due to their ground water flow are less contaminated than the other aquatic environments of that Park and usually maintain constant conditions. These pools could be regarded as refuge areas for restricted species. However the only publication on the zooplankton of these spring pools (except for a reference on the distribution of Brachionus species, MIRACLE et al. 1987) is a paper by ALFONSO AND MIRACLE (1987). In that paper the seasonality of zooplakton (crustacea and rotifera) was studied in three of these springpools during one year. Each one of them presented a distinct fauna. On the other hand, more attention have been given to the zaoplankton of the Albufera lagoon (WISZNIEWSKI 1931, ALFONSO \& MIRACLE 1990, OLTRA \& MIRACLE 1992) because of its greater dimensions, but since it is very contaminated has only banal species.

The aim of the present study is to provide a more complete survey of the rotifer fauna of the best preserved spring-pools of the Albufera Natural Park; which has shown the extraordinary richness of the rotifer assemblages in these environments.

\section{STUDY SITES AND METHODS}

We have studied four among the 40 still existent springpools between rice fields and orchards in the Albufera Natural Park. All of them are hard waters (alkalinity usually 4 to 4.5 
meq $1^{1}$ ) with quite constant conditions, temperature is arround $19^{\circ} \mathrm{C}$ throughout the year.

"Ullal" of "Baldovi" (39" 15' N and $0^{\circ} 19^{\prime} \mathrm{W}$ ) It is the best preserved spring-pool and also the one with the highest water flow (200 and $225 \mathrm{l} \mathrm{s}^{1}$, measured respectively in April and September 1989) that feeds an irregular pool of $80 \times 50 \mathrm{~m}$ maximum dimensions, from which a $3 \mathrm{~m}$ wide drain originates. This drain, $200 \mathrm{~m}$ long, empties finally into an irrigation ditch. The spring-pool is surrounded by rice fields which occasionally drain into it. The pool is no more than $3 \mathrm{~m}$ deep and has a moderately developed macrophitic vegetation. Among the spring-pools of this Park, it has the highest conductivity, around $3 \mathrm{mS} \mathrm{cm}{ }^{1}$, which is due mainly to chlorides because of its closeness to the sea. Mean annual ratios chlorides:sulphates:alkalinity in meq are 4:1.3:1

"Ullal Gros" ( $39^{\circ} 14^{\prime} \mathrm{N}$ and $\left.0^{\circ} 22^{\prime} \mathrm{W}\right)$ is a spring pool with a kidney shaped surface area of $1200 \mathrm{~m}^{2}(57 \times 30 \mathrm{~m}$ maximum dimensions). Its flow was respectively 59 and $781 \mathrm{~s}^{1}$ in April and September 1989 and the water is whitish due to marl suspension and dissolution. Subaquatic vegetation exists only in dispersed patches. In the years of sampling, the spring was surrounded by orchards and a rice field, which has now been converted also into orchards. Mean conductivity is $1.5 \mathrm{mS} \mathrm{cm}{ }^{1}$ and, although alkalinity and sulphate concentrations do not differ very much from those found in Baldovina, chlorides are much lower and the mean annual ratios of chloride: sulphate:alkalinity are $0.9: 1.5: 1$

"Font del Forner" ("Font" catalan name for spring, $39^{\circ} 18^{\prime} \mathrm{N}$ and $0^{\circ} 24^{\prime} \mathrm{W}$ ) is a small spring-pool whose waters produce a $100 \mathrm{~m}$ drain, that empties into an irrigation ditch. This drain collects also water from another spring making altogether a flow of 27-30 1 s' (mesured respectively in April and September 1989). Mean conductivity is $1.5 \mathrm{mS} \mathrm{cm} \mathrm{',}$ corresponding to sulphate-carbonated waters, with anionic ratios chloride:sulphate:alkalinity $=0.7: 3: 1$

'Ullal del Roman?' ( $39^{\circ} 18^{\prime} \mathrm{N}$ and $0^{\circ} 24^{\prime} \mathrm{W}$ ) is a narrow triangular spring pool ( $8 \mathrm{~m}$ of base $\times 50 \mathrm{~m}$ of height) which drains into an irrigation ditch. It is the most contaminated by pesticides and fertilizers and it is periodically "cleaned" to eliminate macrophytes. Its flow was $481 \mathrm{~s}^{\prime}$ and 48.3, respectively in April and September. It is slightly less mineralized than the others with a mean conductivity of 1.4 $\mathrm{mS}$ and a mean alkalinity of 3.9 meq $1^{1}$. Mean annual ratios chloride:sulphate:alkalinity are $0.8: 1.8: 1$

Rotifers were sampled monthly during the years 1986 and 1987 in "Ullal" of "Baldovi" and simultaneously but only during 1986 in Gros and Romani. Quantitative rotifer samples were taken by filtering through a $45 \mu \mathrm{m}$ mesh the water collected with a Ruttner bottle (2.6 I capacity) from a point not far from the shore. At the same time, horizontal tows from and along the shore with a $45 \mu \mathrm{m}$ mesh net were collected. These samples were preserved in 4\% formalin. In November 1989 and June 1990, littoral samples were taken by means of a 45 pm net -attached to a metal $2 \mathrm{~m}$ rod- towed near the submerged vegetation, which were enriched with small pieces of macrophytes collected by hand. Rotifers were studied alive for accurate identification. Another spring "Font del Forner" was added for the littoral collections.

\section{RESULTS AND DISCUSSION}

The study of net samples taken during 1986 and also in November 1989 and June 1990 increased the number of species of rotifers found in the spring-pools of Albufera Natural Park to 108 from a first list of 46 species found in planktonic quantitative samples (ALFONSO \& MIRACLE 1987). These species, grouped according to their genus and habitat, are listed in table 1 with indication of their relative proportions in the samples. Thus, all the species within one genus are placed together, although some of them are not so associated with their habitat heading. Many of the species of this table under the heading of littoral may be also benthic or interstitial, but because of our samples were collected by filtering the water near the shore or among the macrophytes, we just name them littoral. In this table we report the results taken with the three different methods of sampling. Among the 1986 net samples, those taken in June and November gave the higher number of species, so we just selected them for a better relation with the data of the littoral living samples taken in the same months but later years. To complete the list of rotifer species found in these spring-pools and also to show their relative proportions in the open waters, we added in table I the annual means of rotifer species proportions obtained from quantitative plankton samples.

Table 1(A) shows littoral and periphytic species, from which there is very little information for Spanish waters, so many of the species found, among the groups Notommatidae, Dicranophoridae and Bdelloidea, were not recorded in a the catalogue of the Spanish and Portuguese rotifer fauna (VELASCO 1990) and not either in the latter years. We can observe that most of these species were seldomly found in plankton samples except for some Cephalodella species, specially $C$. gibba and $C$. catellina, thus, from our results, these species should be considered also tychoplanktonic. Bdelloids are also frequent in plankton samples, specially in the pool with suspended marls. Some of the species of table 1 
TABLE 1 (A. B and C). Rotifer species From the spring-pools. "Baldovi", "Gros", "Forner" and "Romani". Columns are gouped according to the type of sampling: the first four correspond to data from libe littoral net samples, the following group of six correspond to fixed net samples taken from the shore and the last group to volumetric samples takem from the shore and the last group to volumetric samples taken with an hydrographic bottle. The data are frequencies per thousand for each species relative to

the total number of rotifers in each collection -taken in the indicated mounth and year-for the net samples (First 10 columns) and the annual means of the frequencies per thousand calculated from the volumetric samples taken mounthly during the indicated years.

$\approx$ species not cited in VELASCO $(1990) * *$ new records for the Iberian fauna.

\section{Table 1 (A)}

\begin{tabular}{|c|c|c|c|c|c|c|c|c|c|c|c|c|c|c|c|}
\hline \multirow[t]{2}{*}{ LITTORAL } & & \multicolumn{2}{|c|}{ Baldoví } & \multirow{2}{*}{$\begin{array}{c}\text { Gros } \\
\text { Jun. }\end{array}$} & \multirow{2}{*}{\begin{tabular}{|l|} 
Forner \\
Jun.
\end{tabular}} & \multicolumn{2}{|c|}{ Baldovi } & \multicolumn{2}{|c|}{ Gros } & \multicolumn{2}{|c|}{ Romanf } & \multicolumn{4}{|c|}{ Baldoví Gros Romani } \\
\hline & & Nov. & Jun. & & & Jun. & Nov. & Jun. & Nov. & Jun. & Nov. & Annual & Annual & Annual & Annual \\
\hline & & 1989 & 1990 & 1990 & 1990 & 1986 & 1986 & 1986 & 1986 & 1986 & 1986 & 1986 & 1987 & 1986 & 1986 \\
\hline \multicolumn{16}{|l|}{ Bdelloidea } \\
\hline Philodina citrina & Ehrenterg & 17 & 38 & 102 & 38 & & & 94 & & & & & & & \\
\hline Philodina megalotrocha & Ehrb. & 53 & & 163 & 57 & & & 82 & & & & & & & \\
\hline Philodina megalocephala & Ehrb. & 191 & 80 & & & & & & & & & & & & \\
\hline Philodina acuticomis ${ }^{* *}$ & Murray & 4 & & & & & & & & & & & & & \\
\hline Philodina roseola & Ehrt. & 4 & & & & & & & & & & & & & \\
\hline Aotaria rotatoria & Pallas & 31 & & 20 & & & & & & & & & & & \\
\hline Rotaria macroceros ${ }^{* *}$ & Gosse & 4 & & & & & & & & & & & & & \\
\hline Aotaria macrura & Ehrb. & 9 & & & & & & & & & & & & & \\
\hline Habrotrocha ligula** & Bryce & 4 & & & & & & & & & & & & & \\
\hline Habrotrocha constricta & Dujardin & 22 & & & 19 & & & & & & & & & & \\
\hline Bdelloidea in total & Remane & 336 & 118 & 285 & 114 & 45 & 145 & 176 & 120 & 30 & 285 & 139 & 29 & 339 & 180 \\
\hline \multicolumn{16}{|l|}{ Monogononta } \\
\hline Pygura beauchampia & Edm. & & 4 & & & & & & & & & & & & \\
\hline Ptygura crystalina & Ehrb. & & 16 & & & & & & & & & & & & \\
\hline Collotheca omata comuta & Dobie & & 25 & & & & & & & & & & & & \\
\hline \multicolumn{3}{|c|}{ Paradicranophorus hudsoni ${ }^{* *}$ Glascott } & & & 38 & & & & & & & & & & \\
\hline Dicranophorus forcipatus & Muller & 4 & 8 & & 19 & & & 23 & & & & & & & \\
\hline Dicranophorus grandis ** & Ehrb. & & 4 & & & & & 23 & & & & & & & \\
\hline Dicranophorus hercules"* & Wiszniewsk & 4 & & & & & & & & & & & & & \\
\hline Dicranophorus robustus ** & H.\&M. & 4 & & & & & & & & & & & & & \\
\hline Dicranophorus epicharis ${ }^{* *}$ & \multicolumn{2}{|c|}{ Harring \& Myers } & & & & & & & & & & & & $<1$ & \\
\hline Encontrum lupus ${ }^{* *}$ & Wulfert & 4 & & & & & & & & & & & & & \\
\hline Encentrum saundersiae & Hudson & 9 & & & & & & & & & & & & & \\
\hline Encentrum longipes ${ }^{* *}$ & Wuls. & 36 & & & & & & & & & & & & & \\
\hline Engnatha sagittoides ${ }^{* *}$ & \multicolumn{2}{|l|}{ Wiszniewski } & 4 & & & & & & & & & & & & \\
\hline Pleurotrocha petromyzon ${ }^{* *}$ & Ehto. & & 4 & & & & & & & & & & & & \\
\hline Monommata grandis & Tessin & & & & & & 13 & & & & & & & & \\
\hline Monommata sp. & Bantsch & & & & & 10 & & & & & & $<1$ & & & 1 \\
\hline Notommata glyphura & Wulf. & 18 & & & & & & & & & & & & & \\
\hline Lindia torulosa ${ }^{* *}$ & Dujardin & 4 & & & 38 & 7 & & & & & & & & & \\
\hline Cephalodella gibba & Ehrb. & & 8 & & 19 & & 13 & 10 & 120 & 40 & & 24 & 3 & 80 & 4 \\
\hline Cephalodella catellina & O.F.M & & & & & & 65 & 35 & & 45 & & $<1$ & & 3 & 7 \\
\hline Cephal megalocephala** & Donner & 9 & 4 & & 38 & & & & 120 & & & & & & \\
\hline Cephalodella sterea** & Gosse & 26 & 46 & 81 & & & 78 & 15 & & & & & & & \\
\hline Cephalodella ventripes & Dix.-Nuttall & 13 & 4 & & & & 13 & & 40 & & & & & & \\
\hline Cephalodella misgumus ** & Wulf. & & 4 & & & & & & 80 & & & & & & \\
\hline Cephalodella tinca"* & Wult. & 187 & & & & & 13 & & & & & & & & \\
\hline Cephalodella cyclops ${ }^{* *}$ & Wuif. & 18 & & & & & & & & & & & & & \\
\hline Cephalodella auriculata & Muller & 13 & & & & & & & & & & & & & \\
\hline Cephalodella hoodi & Gosse & 4 & & & & & & & & & & & & & \\
\hline Cephalodella forticula & Ehrb. & & & & & & & & 40 & & & & & & \\
\hline Cephalodella stenroosi** & Wuit. & & & & 19 & & & & & & & & & & \\
\hline Proales daphnicola ${ }^{*+}$ & Thompson & & & & & 26 & & & & & & & & & \\
\hline
\end{tabular}


Table 1 (B)

\begin{tabular}{|c|c|c|c|c|c|c|c|c|c|c|c|c|c|c|c|}
\hline \multicolumn{2}{|c|}{ LITTORAL \& TYCHOPLANKTONIC } & \multicolumn{2}{|c|}{ Baldovi } & \multirow{2}{*}{$\begin{array}{c}\text { Gros } \\
\text { Jun. }\end{array}$} & \multirow{2}{*}{$\begin{array}{l}\text { Forner } \\
\text { Jun. }\end{array}$} & \multicolumn{2}{|c|}{ Baldovi } & \multicolumn{2}{|c|}{ Gros } & \multicolumn{2}{|c|}{ Aomani } & \multicolumn{4}{|c|}{ Baldovf Gros Romanf } \\
\hline & & Nov. & Jun. & & & Jun. & Nov. & Jun. & Nov. & Jun. & Nov. & Annual & Annual & Annual & Antual \\
\hline & & 1989 & 1990 & 1990 & 1990 & 1986 & 1986 & 1986 & 1986 & 986 & 1986 & 6986 & 1987 & 1986 & 1986 \\
\hline \multicolumn{16}{|l|}{ Monogononta } \\
\hline Lecane closterocerca & Schmarda & 17 & 46 & 20 & 57 & 160 & 13 & 47 & 20 & 250 & 160 & 51 & 2 & 44 & 140 \\
\hline Lecane luna & Muller & 9 & 33 & 20 & 153 & 110 & 200 & 15 & & 10 & & 82 & 8 & 9 & 3 \\
\hline Lecane bulla & Gosse & 44 & 32 & 40 & & 53 & & 35 & & 30 & & 11 & 8 & 18 & 16 \\
\hline Lecane lunaris & Ehrenberg & 9 & 16 & 20 & & & & & & 90 & & 13 & & $<1$ & 35 \\
\hline Locane hamata & Slokes & & 55 & & & 47 & 13 & & & 10 & & 5 & & 1 & 6 \\
\hline Lecane guadridentata & Ehrb. & & 118 & & & 91 & & 10 & 80 & & & 52 & 2 & 9 & \\
\hline Lecane papuana & Murtay & & & & & 3 & & 15 & & & & 5 & 4 & $<1$ & \\
\hline Lecane hastata & Murray & & & & & 10 & & 10 & & & & $<1$ & & 5 & \\
\hline Lacans ungulata & Gosse & & & & & & 13 & & & & & $<1$ & & 14 & \\
\hline Lecane of grandis & Murray & & & & & & & & & & & & 68 & & \\
\hline Lecane nana & Murray & & & & & 14 & & & & & & & & & \\
\hline Lecane inemis & Bryce & 62 & & & & & & & & & & & & & \\
\hline Lecane inopinata & \multicolumn{2}{|c|}{ Harring \& Myers } & 8 & & & & & & & & & & & & \\
\hline Lecane pideis ** & A. \& M. & & & & & & & & & & & 2 & & & \\
\hline Lecane tenuiseta * & Harring & & & 20 & & & & & & & & & & & \\
\hline Lecane stenroosi & Meissner & & & & & & & & & & & & & 4 & \\
\hline Lecane aculeata & Jakubski & & & & & & & & & & & & & & 45 \\
\hline Lecane furcata & Murray & & & & & & & & & & & & & & 3 \\
\hline Lecane pyriformis & Daday & & & & & & & & & & & & & & 8 \\
\hline Mytilina ventralis & Ehrb. & & & & & 3 & & & & & & 2 & & & \\
\hline Lophocharis salpina & Ehrit. & & & & & & 13 & & & & & & & & \\
\hline Trichotria tetractis & Ehrb. & & & & & & 13 & 20 & 120 & & & & & 6 & \\
\hline Trichotria pocillum & Muller & & & & & & & 15 & & 40 & & & & 15 & 50 \\
\hline Macrochaetus altamirai & Arevalo & & & & & & & & & & 275 & 11 & 16 & & 137 \\
\hline Squatinella rostrum & Schmarda & & & & 76 & & & & & & & 2 & & & \\
\hline Colurella adriatica & Ehrb. & 18 & 21 & 40 & & 10 & 52 & 23 & 40 & 70 & & 65 & 11 & & 47 \\
\hline Colurella uncin. bicuspidafa & Ehrb. & 9 & 25 & 81 & & 6 & 13 & & & 200 & & 8 & & 1. & 43 \\
\hline Colurella oblusa & Gosse & 13 & 42 & & 19 & & & & & & & & & & \\
\hline Lopadella patella & O.F.M. & 57 & 100 & 163 & 19 & 145 & 65 & 15 & & & & 1 & & 14 & \\
\hline Lopadella ovalis & O.F.M. & & 33 & & & 6 & & 15 & & 65 & 150 & 36 & 5 & 20 & 55 \\
\hline Lepadella thomboides & Gosse & & 22 & & & 10 & & & & & & 1 & & & \\
\hline Lepadella triptera & Ehrb. & & 80 & & & 20 & & & & & & & & & \\
\hline Scaridium longicaudum & O.F.M. & & 4 & & & & & 10 & & & & 2 & & 10 & 1 \\
\hline Lacinularia elliptica " & Shephard & & & & & & & & & & & 1 & & & \\
\hline
\end{tabular}


Table 1 (C)

\begin{tabular}{|c|c|c|c|c|c|c|c|c|c|c|c|c|c|c|c|}
\hline \multicolumn{2}{|c|}{ PLANKTONIC SEMIPLANKTONIC } & \multicolumn{2}{|c|}{ Baldovi } & \multirow{2}{*}{\begin{tabular}{|l|} 
Gros \\
Jun. \\
\end{tabular}} & \multirow{2}{*}{$\begin{array}{l}\text { Fomer } \\
\text { Jun. }\end{array}$} & \multicolumn{2}{|c|}{ Baldovf } & \multicolumn{2}{|c|}{ Gros } & \multicolumn{2}{|c|}{ Pomani } & \multicolumn{4}{|c|}{ Baldoví Gros Romaní } \\
\hline & & Nov. & Jun. & & & Jun. & Nov. & Jun. & Nov. & Jun. & Nov. & Annual & Annual! & Annual & Annual \\
\hline & & 1989 & 1990 & & 1990 & 1986 & 1986 & 1986 & 1986 & 986 & 1986 & 1986 & 1987 & 1986 & 1986 \\
\hline Monogononta & & & & & & & & & & & & & & & \\
\hline B. quadridentatus f. brevispi & nus Ehrb. & & 4 & & & 21 & & & & & & 13 & 42 & & \\
\hline B. quadr. f. duniorbicularis & Skorikor & & 4 & & & 21 & & & & & & 2 & 114 & & \\
\hline Bractionus plicatilis & O.F.M & & & & & & & & & & & 83 & 174 & 54 & 90 \\
\hline Brachionus urceolaris & Mulier & & & & & & & & & & & 1 & 7 & 2 & \\
\hline 8. bidentata $f$ inemis & Rousselet & & & & & 10 & & & & & & 3 & $<1$ & & \\
\hline B calyciftorus f typica & Pallas & & & & & & & & & & & 17 & 59 & & \\
\hline E cabyolf. $f$, anuraeifomis & Brehm & & & & & & & & & & & 30 & & & \\
\hline Erachionus angularis & Gosse & & & & & & & & & & & 30 & 39 & & \\
\hline Kerateffa cochlearis & Gosse & & & & & 10 & 26 & & & & & & & 4 & 11 \\
\hline Keratella quadrata & Muller & & & & & & 13 & & & & & 99 & 125 & 4 & 36 \\
\hline Keratella tropica & Apstein & & & & & & & & & & 130 & 11 & 81 & & 15 \\
\hline Notholca acuminata & Ehrb. & & & & 76 & & & & & 10 & & & & 5 & 6 \\
\hline Notholca labis & Gosse & & & & & & & & & & & & & & $<1$ \\
\hline Notholca salina & Focks & & & & & & & & & & & & 75 & 6 & $<1$ \\
\hline Notholca striata & O.F.M. & & & & & & & & & & & & & 2 & \\
\hline Notholca squamula & O.F.M. & 18 & & & & & & & & & & & & & \\
\hline Euchlanis dilatata & Ehrb. & 13 & 85 & 224 & 307 & 53 & 13 & 20 & 180 & 110 & & 46 & 47 & 94 & 12 \\
\hline Euchlanis dapidula * & Parise & & & & & 79 & & & & & & 3 & & & \\
\hline Tripleuchlanis plicata & Levander & & 12 & & & 3 & & 35 & & & & 2 & 3 & 1 & \\
\hline Trichocerca porcellus & Gosse & & & & & & 13 & 15 & & & & 8 & & 11 & 25 \\
\hline Trichocerca elongata * & Gosse & & & & & & & 10 & 40 & & & 2 & & 26 & 1 \\
\hline Trichocerca brachyura & Gosse & & & & & 6 & & & & & & & & & \\
\hline Trichocerca sulcata ** & Jennings & & & & & 3 & & & & & & & & & \\
\hline Trichocerca longiseta & Schrank & & & & & & & 15 & & & & & & & \\
\hline Trichocerca bicristata & Gosse & & & & & & & 15 & & & & & & & \\
\hline Synchasta oblonga & Ehib. & 36 & & & & 3 & 200 & 128 & & & & 96 & 16 & 179 & \\
\hline Synchaeta pectinata & Ehrt. & & & & & & & 40 & & & & & & & \\
\hline P. vulgaris-dolichoptera & Carlin & & & & & & & 170 & & & & 34 & 47 & 2 & \\
\hline Polyarthra longiremis & Carlin & & & & & & & 40 & & & & & & 1 & \\
\hline Asplanchnopus hyalinus & Haming & & & & & 6 & & & & & & $<1$ & & & \\
\hline Asplanchnopus multiceps " & Schrank & & & & & 6 & & & & & & $<1$ & 13 & 2 & \\
\hline Asplanchna girodi & De Gueme & & & & & 3 & & & & & & $<1$ & & & \\
\hline Testudinella patina & Hermann & & & & & & & & & & & & 3 & 4 & \\
\hline Hexarthra fennica & Levander & & & & & & & & & & & & 2 & & \\
\hline
\end{tabular}


(A) are very rare, with a very few world-wide records. Among them are those described by Wizsniewski in the psammon and classed as psammobiotic, i. e. exclusive from this habitat (WIZSNIEWSKI 1934, 1937) such as Erignatha sagittoides and Dicranophorus hercules. Psammobiotic species have seldomly been studied and e. g. E. sagittoides (Fig. I) has been reported only from Poland and Rumania (RUDESCU 1960). Moreover, we have found in the spring-pools several species classified by WISZNIEWSKI $(1934,1937)$ as psammophiles, i.e. constant elements in the psammon, although present in other habitats (mainly species of the genus

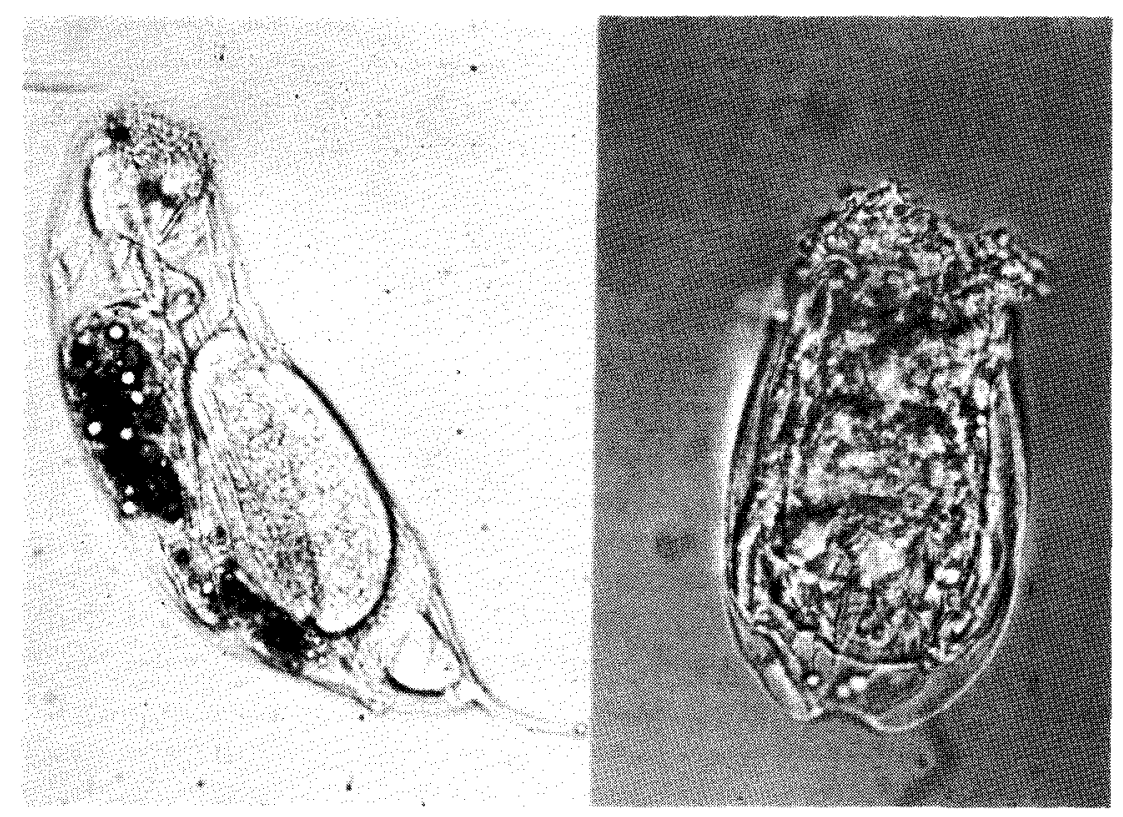

FIGURE 1.Light micrographs of Erignata saggitoides and Euchlanis dapidula.

Cephalodella, among them $C$. verztripes and $C$. auriculata are the less frequent in other habitats). This is to be expected due to the subterranean feeding of the pools.

Because of the reduced dimensions, shallowness and high water flow of these environments, dominant rotifers are mainly tychoplanktonic species - Table 1 (B)-, even in the planktonic quantitative samples. The genus Lecane is the most represented with 19 species, some of which are uncommon, e. g. L. pideis, L. inopinata, L. inermis and L. aculeata (SEGERS 1995). Moreover, many species of the genera placed in table 1 (C) -tending to group the rotifers with a more pelagic distribution- are semiplanktonic species, i. e. with more affinities to littoral environments, that is the case of the species of the genera Euchlanis and Trichocerca, specially T. sulcata, T. longiseta and T. brachyura. The two last named species are also found in the psammon (KOSTE 1980).

The spring-pools are rather different; "Baldovi" and "Forner" have more macrophitic vegetation. "Baldovî" is closer to the sea and has a slightly higher salinity than the other spring-pools, it is the less polluted and shows a much higher diversity. "Gross" is characterized by a turbid water due to suspended marls and its main feature is a high relative proportion of bdelloids in all types of sample collections. "Romani", subject to strong human impact, shows a striking reduced diversity. The rotifer fauna differs little in the euryoic species, but they differ very much in the less frequent species. For instance, great differences can be observed in the congeneric clusters in table 1 , where the species have been arranged to have first the more ubiquitous and then the exclusive for the different pools (in this order: Baldovi, Gros, Romani and Forner). Lecane aculeata was quite frequent in Romani and never found in the other pools. these pools had also other exclusive species of this genus, Gross: L. stenroosi and Baldovi: L. grandis, L. nana, - indicators of saline conditions- besides the exclusive presence of three of the uncommon species (table $1 \mathrm{~B}$ ). Among Cephalodella and Triclzocercn, the second and third genus in importance (with respectively 12 and 6 species) a differential distribution can also be easily observed in table 1 .

The species in all these pools correspond to freshwater taxa, although there are some indicators of coastal environments or at least indicators of some salinity tolerance, such as Asplachnopus hyalinus, Dicranophorus forcipatus, Cephalodella megalocephala, Tripleuchlanis plicata, Trichocerca longiseta and the Notholca species: N. marina, N. salina, N. striata, as well as the Lecane species: L. grandis, L nana, $L$. hastata and $L$ stenroosi, which tolerate saline conditions. The constant and warm temperature of these environmentsalso facilitates the development of warm stenotherms as the Lecane species $L$. nana, $\mathrm{L}$ papuana, $L$ inopinata or the species of Cephalodella which have been found in waters coming from thermal springs as $C$. ventripes and C. catellina (RUDESCU 1960).

From the biogeographical point of view, most of the species have a cosmopolitan distribution and, if not, they are from the 


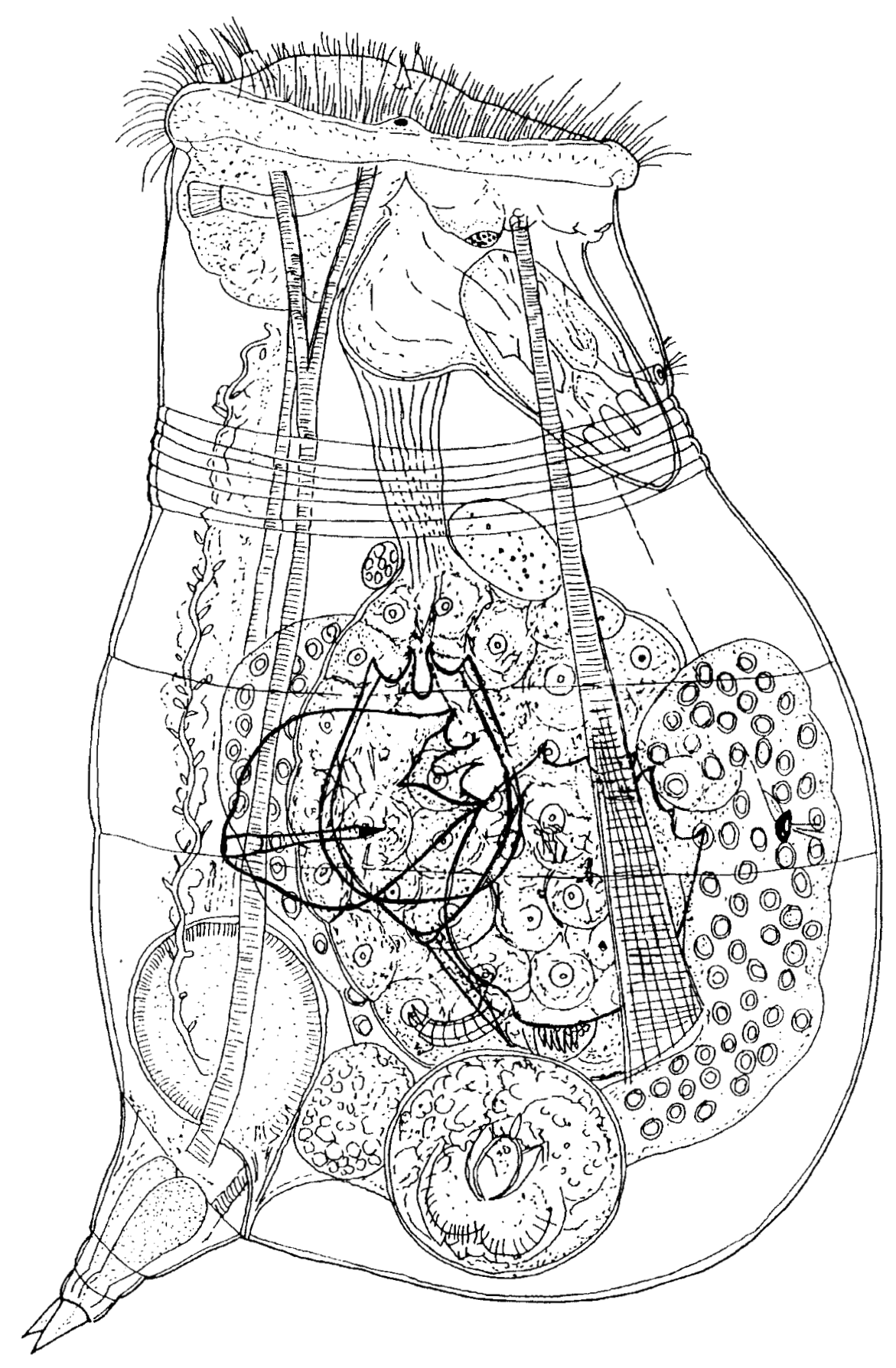

FIGURE 2. Ilnstration of Asplachnopus multiceps showing ingested preys; Lecane quadridentata was the main prey species for the population of A multiceps in Baldoví spring-pool. 
palaeartic fauna, with a few tropical-subtropical elements. However these environments are interesting for the presence of rare species. Some of them, although rare, are widespread through all continents, such as Asplachnopus multiceps (KOSTE 1987) drawn in fig. 2, the rare genus and species Paradicranophorus hudsoni (KOSTE \& POLTZ 1983) and Macrochaetus altamirai (KOSTE \& SHIELD,1989). However many of these species have only been recorded from few places in Europe, as the already mentioned E. sagittoides, the species of Encentrum: E. lupus and E. longipes and the species of Cephalodella: C. misgurnus, C. cyclops, and Cephalodella tinca. Still others have almost no other record than the place of its description, such as L. pideis (SEGERS 1995) and E. dapidula (PARISE 1966, microphotograph of a speciment from Baldoví pool in Fig. 1), although the latter has been recently found in the coastal wetlands of Donana National Park (S. Spain, MAZUELOS et al.1993). On the other hand. some of the warm water species or forms within species have a tropical and subtropical distribution, such as Brachionus bidentata f. inermis, Keratella tropica, Lecane inermis, Lecarze papuana, Lecane aculeata and Lacinularia elliptica. The latter, not recorded before from the Iberian Peninsula, has recently been found in Menorca Island (DE MANUEL 1990).

We have confirmed the high diversity expected in this environment, for instance the rotifer diversity of one littoral net tow in "Baldovî" was as high as 4.4 bitslind (Shannon-Wiener index) in 6 June 1990 and 4.2 bitslind in 27 November 1989, corresponding respectively to 31 and 30 species. These values are comparable to the ones obtained in ecosystems considered as having the higher rotifer diversities, such as dune lakes or flood plain habitats ( et al. 1989, TAN \& SHIEL 1993). Diversity of quantitative plankton samples in all the studied spring-pools was over 3 bits during the summer. The richness in rotifer species confirms also the interest of this area, and the hypothesis that, this or neighbouring areas, ice-free during glaciations, may have retained for long coastal freshwater environments without extreme perturbations. The endemics of crustacea, molusca and ciprinodontid fishes (MARGALEF 1983), mentioned in the introduction, may be considered derived from emigrants from the East (Ponto-Caspian region) which could differentiate in the Iberian Peninsula in the less affected sites by the glaciations. They are or were found until very recently in this Natural Park, mainly confined to the better preserved spring-pools.

\section{ACKNOWLEDGMENTS}

We thank Juan Miguel Soria for his data on the flow and chemistry of the spring-pools.

\section{REFERENCES}

ALFONSO, M.T. \& M.R. MIRACLE, 1987. Estudio comparativo del zooplancton en tres ullales del parque natural de la Albufera de Valencia. Limnetica 3 (2):263-272.

ALFONSO, M.T. \& M.R. MIRACLE, 1990. Distribución espacial de las comunidades zooplanctónicas de la Alhufera de Valencia. Scientia Gerundensis 16 (2):11-25.

DE MANUEL, J., 1990. Contribution to the knowledge of the rotifer fauna (Rotifera: Monogononta) from Minorcan inland waters (Balearic isles, Spain). Limnetica 6:119-130.

KOSTE, W., 1987. Ein Radertier, das Krebse verschlingt: Asplanchnopus multiceps. Mikrokosmos 76:171-175.

KOSTE, W. \& J. POLTZ (1983). Über ein seltenes. schlammbewohnendes Radertier Paradicranophorus hudsoni (GLASCOTT 1893) ausdem Dümmer, NWDeutschland. Osnabrücker naturwiss. Mitt. 10: 27-41.

KOSTE, W. \& R. J. SHIEL (1989). Rotifera from Australia inland waters. III. Euchlanidae, Mytilinidae and Trichotriidae. Trans. R. Soc. S. Aust. 113: 85-1 14.

MARGALEF, R., 1983. Limnologia. Omega S.A. Ed. Barcelona, $1010 \mathrm{pp}$.

MAZUELOS, N., J. TOJA \& C. GUISANDE, 1993. Rotifers in ephemeral ponds of Doiiana National Park. Hydrobiologia 2551256: 429-434.

MIRACLE, M.R., M. SERRA, E. VICENTE \& C. BLANCO, 1987. Distribution of Brachionus species in Spanish Mediterranean wetlands. Hydrobiologia 147:75-81.

OLTRA, R. \& M.R. MIRACLE, 1992. Seasonal sucession of zooplankton populations in the hypertrophic lagoon Albufera of Valencia (Spain). Arch. Hydrobiol 124 (2):187204.

PARISE, A., 1966. The Genus Euchlanis (Rotatoria) in the Marsh of Fucecchio (Central Italy) with Description of a New Species. Hydrobiologia 27:328-337.

RUDESCU, R. 1960. Rotaroria. Fauna Republicii Populare Romine, Trochelminthes II. Acad. R.P.R.:1192pp.

SEGERS, H. 1995. Rotifera. Vol. 2: The Lecanidae (Monogononta). Guides to the identification of the Microinvertebrates of the Continental Waters of the World. SPB Academic Publishing, The Hague : 226 pp.

SHIEL, R.J., W. KOSTE \& L.W. TAN, 1989. Tasmania revisited: rotifer communities and habitat heterogeneity. Hydrobiologia 1861187:239-245.

TAN, L.W. \& R.J. SHIEL. 1993. Responses of billabong rotifer communities to inundation. Hydrobiologia 255/256:361-369.

VELASCO, J.L., 1990. Lista fannística y bibliográfica de los 
Rotíferos (ROTATORIA) de la Peninsula Ibérica e Islas Baleares y Canarias. Listas de la flora y fauna de las aguas continentales de la Peninsula Ibérica. Publ. num. 8: $1-195$.

VICENTE, E. \& M.R. MIRACLE, 1992. The coastal lagoon Albufera de Valencia: an ecosystem under stress. Limnetica 8: 87-100.
WISZNIEWSKI, J., 1931. Sur quelques rotifères trouvés en Espagne. Arch. Hidrob. et Ichtiol. Varsovia 6:1-41.

WISZNIEWSKI, J.,1934, Recherches Ccologiques sur le psammon. Archiwum Hydrobiol. Ryb., Suwalki 8:162-272.

WISZNIEWSKI, J. 1937. Différenciation Ccologique des Rotifères dans le psammon d'eaux douces. Ann. Mus. Zool. Pol., Warszawa 13: 1-13. 